\title{
30. \\ PROFESSOR PABLO DE AZCÁRATE AND \\ THE NATIONALITIES OF YUGOSLAVIA
}

\section{Giuseppe Motta}

UDK: 323.1(497.1)“191/2“

Prethodno priopćenje

Summary: This article is focused on the work of Pablo de Azcárate inside the League of Nations and the special minority section established within the structure of the Secretariat. As director of this section, de Azcárate left a complete and interesting work about his experience during a phase in which the League resented from the difficult international atmosphere and from the troublesome relationships among the different ethnic groups of Central-Eastern Europe. In this context de Azcárate had to deal with many different minority questions and, through his activity and the regular journeys made in Yugoslavia and in other European countries, he had the opportunity to leave very interesting comments on the situation of the nationalities and minorities.

Keywords: national minorities, League of Nations, Yugoslavia, multi-ethnic coexistence

\section{The life and work of Pablo Florez de Azcárate (Madrid 1890 - Geneva 1971)}

\footnotetext{
ablo Florez de Azcárate came from a family with liberal traditions, who settled in Madrid but was geographically rooted in the regions of León and Navarra. Pablo studied law in Madrid and completed his formation in France and England, where he started to be interested in the international law, a field which was rapidly developing during the first decades of the XX century. He started his university career as professor of administrative law at the University of Santiago de Compostela, and in 1915 he moved to Granada, where he continued to work in the university until 1922, when he started his diplomatic adventure. In 1918 he also commenced his political career as deputy for the circumscription of León in the ranks of Melquíades Álvarez's Reforming Party, while in the following years he entered the diplomatic service.
} 


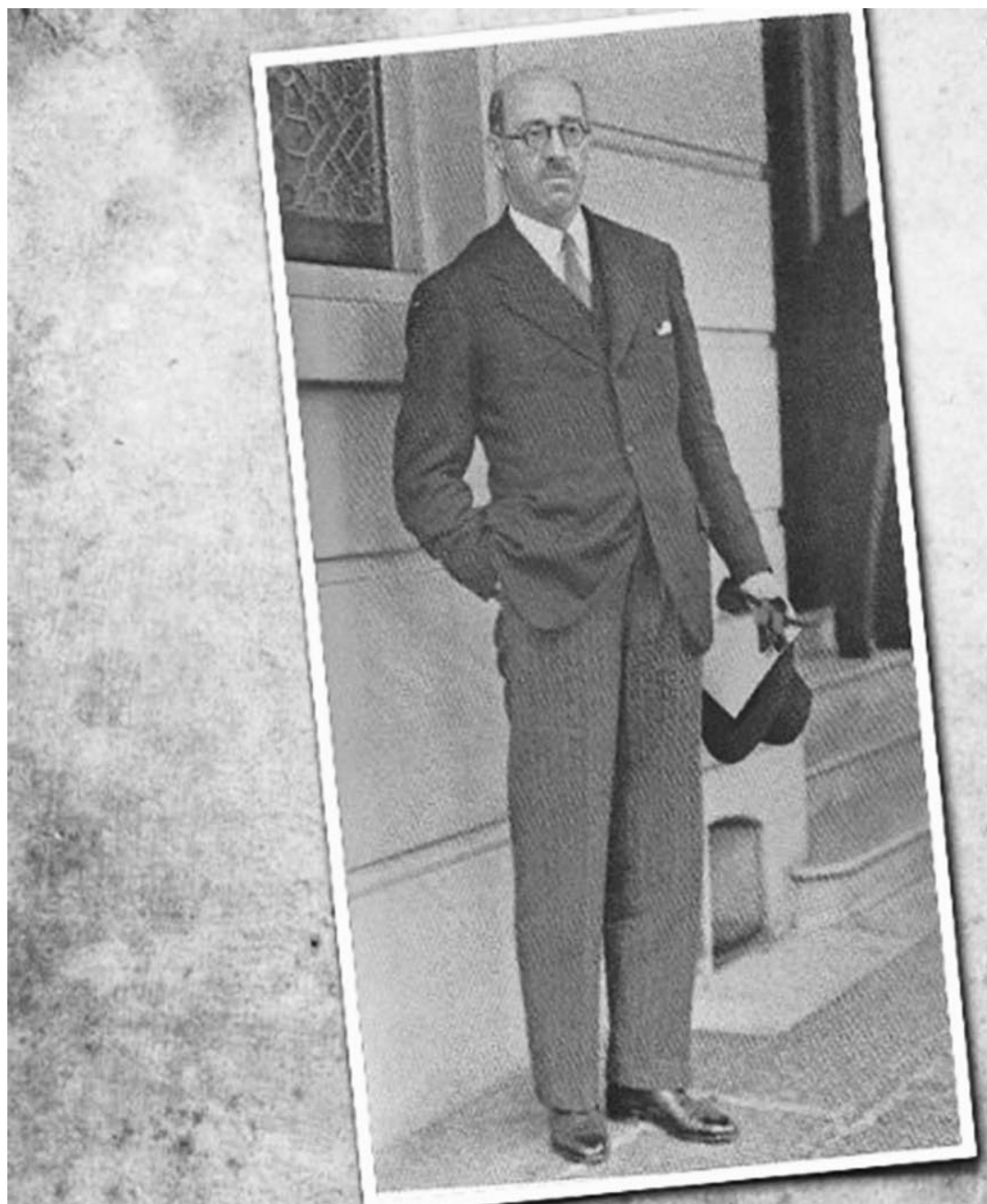

La recuperación de un gran diplomático: el profesor Pablo de Azcárate Ángel Viñas Catedrat1co de 3oononla Apl1cada, D1plonático e H1atoriador 30 de Noviembre, 20:00h Salón de actos de la Fundación Sierra Pambley

Figure 1. Spanish Republican culture of remembrance: invitation for the conference devoted to the Republican diplomat Professor Pablo de Azcárate (2010) 
He was first engaged in the League of Nations as a technician, a legal expert inside the General Secretariat of the League and, in particular, in the minority section of the aforesaid secretariat, which was headed by the Norwegian Erik Colban. ${ }^{1}$

During these years he had the opportunity of investigating and studying the conditions of the national minorities in Central-Eastern Europe and every year he visited many regions in this part of the continent accompanying the director of the section, Erik Colban. As a matter of fact, it was usual that a delegation formed by Colban and by two or three of his assistants spent some months every year in the countries which were interested by the international treaties concerning the protection of minorities, primarily in Poland, Czechoslovakia, Romania, Yugoslavia and Greece, whose population was composed by important portions of minorities. ${ }^{2}$ In 1929-1930 he was one of the secretaries involved in a complex reform of the League procedure concerning the protection of minorities. De Azcárate was a member of the commission who analysed the practice and the results obtained during the Twenties and tried to reform it in order to improve the effectiveness of the League's control.

In 1931 de Azcárate became the director of the minority section, replacing Erik Colban and Aguirre de Carcer. He kept this function until 1934, and in this period he assisted as mediator in numerous international controversies, for example in the German-Polish dispute over Upper Silesia, or in the Romanian-Hungarian one regarding the conditions of the Szeklers (a Magyar population) in Transylvania.

These cases showed that the work of the League in the protection of minorities met with the opposition of many sectors as it usually did not satisfy both the parties involved in the dispute: neither the minorities and their Kin States, which asked for strong condemnations and radical reforms; nor the States which had to continuously rebut the charges and viewed the intervention of the League of an unjust limitation of their sovereignty.

He kept on working in the Secretariat of the League until 1936, while in the following years his interests were directed in the Spanish situation, which experienced the tragic period of the civil war. He re-organized the Spanish embassy in Paris and he became ambassador in London for the republican government of Spain. In this post, he tried to gain the support of the British government for the Spanish republic, clashing with Neville Chamberlain, who proclaimed the principle of non-intervention in 1937. While in England, he continued to be in contact with the representatives of many parties and associations promoting the interests of the Spanish republic, even if without obtaining good results, as he

\footnotetext{
On the role and activity of the Secretariat, Zara STEINER - Egon F. RANSHOFEN-WERTHEIMER, The International Secretariat: A Great Experiment in International Organization, Washington DC 1945. In general, on the League of Nations, The Lights That Failed: European International History, 1919-1933, New York 2005; Francis Paul WALTERS, A History of the League of Nations, New York 1950, 76; Martti KOSKENNIEMI, The Gentle Civilizer of Nations: The Rise and Fall of International Law, 1870-1960, New York 2004; Elmer BENDINER, A Time for Angels: The Tragicomic History of the League of Nations, New York 1975; Marie-Renée MOUTON, La Société des Nations et les intérêts de la France (1920-1924), Bern 1995; John SPENCER BASSETT, The League of Nations, a Chapter in World Politics, New York 1930; David HUNTER MILLER, The drafting of the Covenant, New York 1928; Frederick Samuel NORTHEDGE, The League of Nations: its life and times, Leicester 1986; Francis Paul WALTERS, A history of the League of Nations, Westport 1986.

2 After the first world war, some counted more than 7 million of Germans under foreign rule (7.594.000) and almost 3 million of Magyars plus 1.339.000 Bulgarians; the Ruthenes were 3.700.000 in Poland, 432.000 in Czechoslovakia and 300.000 in Romania. The total number was 16.815 .000 people. N. BUXTON - T. P. CONWIL-EVANS, Oppressed peoples and the League of nations, London - Toronto, 1922, 80-82. According to the combination of the data quoted by P. Eberhardt, this number was even larger and it could calculated around 18 million. (Piotr EBERHARDT, Ethnic Groups and Population Changes in Twentieth-Century Central-Eastern Europe. History, Data, and Analysis, New York - London 2003.) On the role that inequality had as a source of conflict for the minorities, Ekkehart KRIPPENDORFF, "Minorities, Violence, and Peace”, Journal of Peace Research, 16/1979., no. 1, 27-40.
} 
reminded in his work dedicated to his three years as ambassador, Mi embajada en Londres durante la Guerra Civil Española. ${ }^{3}$

He carried out his duties also approaching the League of Nations, criticizing the international support for the principle of non-intervention, and denouncing the Italian interference in the Spanish war. He also defended the republican government of Spain when Sir Frederic G. Kenyon attacked in The Times the Spanish policies in the field of the protection of the historical and artistic heritage. His efforts for the interests of Spanish republic continued in the following years, and cost him his role, as in 1939 he lost his post as ambassador and was equally purged from the university by a ministry order. ${ }^{4}$

He tried to mediate with the British government in order to obtain reasonable and human conditions for the vanquished members of the republican government, and had to assist to the international recognition of Franco's government and the definitive defeat of the republic. When he was replaced as ambassador by Jacobo Fitz-James Stuart y Falcó, XVII Duque de Alba, de Azcárate decided not to come back to Spain but remained abroad. In France he coordinated the evacuation of the Spanish refugees as president of the Servicio de Evacuación de Refugiados Españoles (SERE), helping many people to flee to Mexico, Chile and Argentina. During the second world war he came back to London, where he organized a structure for the Spanish refugees in England, such as Negrín, Santiago Casares Quiroga, Francisco Méndez Aspe, Manuel de Irujo y Carles Pi i Sunyer. In 1941 he created the Asociación de Exiliados Españoles, teaching to Spanish students in the university of Cambridge.

In 1946 de Azcárate joined the newborn Organization of the United Nations (OUN) and in 1948 he was appointed as secretary of the special committee of mediation in Palestine, where the British mandate was ending and the Jewish State was under formation. He arrived in Jerusalem in March 1948, and assisted to the outbreak of the first Arab-Israel war. He tried to find a compromise between the Jewish community and the Arabic legion, but could not count with any military force and retired to Amman and Cairo. De Azcárate described the situation of Palestine and of the Arab refugees, whose tragedy damaged the reputation of all the countries in that region and of the international institutions as well.

In 1952 he left the diplomatic career and settled in Geneva, where he had lived in the period he worked for the League of Nations and started to write about his experiences. Among his works, in 1960 he published Wellington y España, and in 1966 the more important Misión en Palestina: nacimiento del Estado de Israel (in English Mission in Palestine, $1948-1952)^{5}$

\footnotetext{
Pablo DE AZCÁRATE, Mi embajada en Londres durante la Guerra Civil Española, Barcelona 1976.

“...se separa definitivamente por ser pública y notoria la desafección de los catedráticos universitarios que se mencionarán al nuevo régimen implantado en España, no solamente por sus actuaciones en las zonas que han sufrido y en las que sufren la dominación marxista, sino también por su pertinaz política antinacionalista y antiespañola en los tiempos precedentes al Glorioso Movimiento Nacional. La evidencia de sus conductas perniciosas para el país hace totalmente inútiles las garantías procesales que, en otro caso constituyen la condición fundamental en todo enjuiciamiento, y por ello, este Ministerio ha resuelto separar definitivamente del servicio y dar de baja en sus respectivos escalafones a los señores: Luis Jiménez de Asúa, Fernando de los Ríos Urruti, Felipe Sánchez Román y José Castillejo Duarte, catedráticos de Derecho; José Giral Pereira, catedrático de Farmacia; Gustavo Pittaluga Fattorini y Juan Negrín López, catedráticos de Medicina; Blas Cabrera Felipe, catedrático de Ciencias; Julián Besteiro Fernández, José Gaos González Pola y Domingo Barnés Salinas, catedráticos de Filosofía y Letras, todos ellos de la Universidad de Madrid. Pablo Azcárate Flórez, Demófilo de Buen Lozano, Mariano Gómez González y Wenceslao Roces Suárez, catedráticos excedentes de Derecho". (Orden del 3 de febrero de 1939, Ministerio de Educación Nacional.)

His works included the translations of classical books written by John Stuart Mill and Robert Filmer, and: El régimen parroquial en Inglaterra (1912); La intervención administrativa del Estado en los ferrocarriles (1917); La guerra y los
} 
In 1968 he donated his documents to the Institución Libre de Enseñanza, and in 1971 he died in Geneva. He was 81 years old. His diaries were partially published by his son, Manuel Azcárate, who was in the Communist party since 1981 and in 1994 edited the book Derrotas y esperanzas (Defeats and hopes, Tusquets Editores, Premio Comillas 1994).

\section{The work of the League of Nations and the minorities in Yugoslavia}

As it has been mentioned, Pablo de Azcárate had an important role in the activity of the League of Nations and especially in the protection of minorities, which became a matter of international concern after the special treaties signed in 1919 and 1920 by Poland, Czechoslovakia, Romania, the Kingdom of Serbs, Croats and Slovenes, and Greece. These treaties were soon followed by many other multi-lateral or bilateral agreements (for example the Upper Silesian convention signed by Poland and Germany in 1922) and by the unilateral declarations that many States released in order to be admitted as members of the League (Estonia, Lithuania, Latvia, Albania).

All these acts placed the protection of minorities under the international control and jurisdiction of the League of Nations, which starting from 1920 defined a complex procedure in order to activate the protection of minorities before the Secretariat and the Council of the League itself. According to Tittoni's resolution of the $20^{\text {th }}$ of February 1920 the procedure started with a petition to the Council, an act which had to be interpreted as une information pure et simple. The petition could be sent not only by the States, but also by the minorities, and could be followed by the replies of the State involved. If the petition was admissible, a special committee composed by three members (it was called committee of three) was appointed to study the case and, when considering it in violation of the treaties, it forwarded the study to the Council.

Individual Council members had the unique privilege of placing complaints on the agenda, giving way to the petitions received, deciding how much pressure to put on the governments and, eventually, relocating the final decision to the Permanent Court of Justice. When the petition was handled by the Council, the latter had to "endeavour to effect a settlement of the dispute" (art. 15 of the Covenant) and to find a compromise between the States. Only at the end of the procedure, after the negotiations and the mediation of the special committee and also of the Council, the dispute had the possibility to be analysed by the Court of Justice - with a decision or a simple advisory opinion - where only member States could be represented. ${ }^{6}$

servicios públicos de carácter industrial (1921); La Liga de las Naciones y las minorias nacionales (1944); Spain: past and future (1945); Memoria sobre Los “Vaughan Papers" (1957); La intervención nazi-fascista en la guerra de España (1957); La guerra hispano-americana (1960); Wellington y España (1960); Mission in Palestine, 1948-1952 (1966); La cuestión universitaria: epistolario de Francisco Giner de los Ríos (1967); Gumersindo de Azcárate, estudio biográfico documental (1969); Sanz del Río (1814-1896) (1969); Tres rincones del siglo XIX leonés (1971); Mi embajada en Londres durante la Guerra Civil Española (1976); En defensa de la República (2010, editado por Ángel Viñas).

6 The problem of minorities interested interwar jurists and observers, who animated a lively discussion on the effectiveness of the treaties and the procedure within the League of Nations. Helmer ROSTING, "Protection of Minorities by the League of Nations", The American Journal International Law, 17/1923, no. 4, 641-660; H. DICKINSON, Les droits des Minorités, Bruxelles 1924; Marcel RICHARD, Le droit de pétition, Paris 1932. International historiography 
A first-hand account of how these problems were dealt with and solved during the interwar period could be found in de Azcárate's work, La Liga de las Naciones y las minorías nacionales (1944), which was translated in 1945 and published by the Carnegie Endowment for International Peace.

De Azcárate analyzed the historical and political reality of those States which were mainly interested by these international regulations, that is to say the signatories of the special treaties in 1919. These countries, as a matter of fact, were enlarged by the peace-treaties and hosted inside their frontiers consistent portions of minorities. Yugoslavia, for example, which is the subject of this article, in 1921 hosted 5.271.500 Serbs, Macedonians and Montenegrins (44\%); 2.884.700 Croats (24.1\%); 1.020 .000 Slovenes (8.5\%); 755.300 Bosnian Muslims (6.3\%); 505.800 Germans (4.2\%); 467.700 Hungarians (3.9\%); 439.000 Albanians (3.7\%); 231.100 Romanians (1.9\%); 150.300 Turks (1.3\%) and many other minorities like Italians and Slovaks. ${ }^{7}$

The Kingdom of Serbs, Croats and Slovenes was internationally recognized in accordance with the principle to self-determination even if the three main ethnic components (Slovenes, Croats and Serbs) accepted the idea of a troplemenski narod (three-tribal people) but safeguarded their peculiarity and had substantially different ideas about the integration and the structure of their State.

The new State was a complex combination of languages, faiths and traditions. Catholicism and Protestant cults were present in the western areas like Slovenia and Croatia, Orthodoxy was the religion of Serbs, while Islam was still practiced by many people in Bosnia, Montenegro, Kosovo and Macedonia. In conclusion, the Kingdom of Serbs, Croats and Slovenes became a huge melting pot of different nationalities who soon found many causes of disagreement among them.

The problem was further aggravated by the fact that the proportions of minorities were absolutely more important in certain regions of the State, for example in those next to the boundaries, and their presence was associated to the dangers coming from the neighboring States. At the same time, it has to be stressed that in 1919 the idea of nationality and minority was not so refined as today and in many cases it was not clear if a group represented a minority or a part of another nationality. The Bosnian Muslims were a religious or a national minority? Were they Serbs, Croats or Bosniaks? The inhabitants of Macedonia were Southern Serbs, Bulgarians or Macedonians? These questions find an easy answer today, but were not so simple in the Twenties, when they generated wide and polemical debates.

The League's consultants had to deal also with these reflections and underlined that in some cases it was not possible to talk about minorities in the technical sense of the word. The Slovaks, for example, as well as the Croats and the Slovenes, were titular nationalities of their respective States and could not be regarded as minorities. A very difficult question,

dedicated very interesting and documented works to the Minority treaties of Versailles. In German, Christoph GÜTERMANN, Das Minderheitenschutzverfahren des Völkerbundes, Berlin 1979; Bastiaan SCHOT, Nation oder Staat? Deutschland und der Minderheitenschutz, Marburg 1988; in French, Jacques FOUQUE-DUPARC, La protection des minorités de race, de langue et de religion, Paris 1922; Harold William Vazeille TEMPERLEY, History of the Peace Conference, vol. V, London 1924; Carlile Aylmer MACARTNEY, National States and National Minorities, Oxford 1934.

Piotr EBERHARDT, Ethnic Groups and Population Changes, New York - London 2003, 360.

Note of Van Hamel from the secretary general (October 8, 1919). Historical Archives of the League of Nations (HALN), Section 41, box R1620, dossier 1279. Notes of de Azcárate of August 1927; HALN, section 41, R1700, dossier 51127. 
moreover, was represented by the Slavic Macedonians of Yugoslavia. The presence of such a group was excluded by the Serb government, according to which no Bulgarian minority existed: the minority section of the League, instead, was skeptical about this thesis but believed that considering Macedonian petitions meant a denial of the thesis of a sovereign State and, consequently, accepted the theory of Belgrade, even if continuing to analyze the protests coming from Macedonia. ${ }^{8}$

These petitions occupied a privileged space and in the case of Yugoslavia represented the most important minority issue under the attention of international institutions. The other minorities created less problems and were divided by de Azcárate into different categories.

The Germans and the Hungarians represented the former dominant nationalities and had many features in common: both were supported by their respective governments and were more culturally and politically developed than the Slav population. According to de Azcárate, they represented an excellent example of how minorities were affected by a drastic change in their conditions in a phase of transition from one regime to another.

The importance of their Kin States, further, influenced the attitude of Belgrade authorities, which showed to be quite indulgent with the Germans and, on the contrary, very firm with the Magyars. This indulgence, anyway, did not mean that the relationships were generally free from crisis and controversies. If in Vojvodina the support of Germans was necessary to strengthen the anti-Magyar policy of the government, in other regions the treatment deserved to them was absolutely coherent with the nationalist point of view of Belgrade, as denounced in the political debates and before the international institutions. The international forum became the only place where Germans could address their grievances after the turn of 1929, and the banning of the Partei der Deutschen, as it was stressed in the Petition issued in 1930 by the lawyer Dr. Walter Riebl. This petition was focused on the statute of the association Deutsches Haus and the property of a building erected in 1903. In 1925, the latter was confiscated thanks to a decree of 1915 concerning the goods of enemy subjects, and was transferred to another organization, Celjski Dom, which pretended to have the same goals of the German association. The problem relied in the fact that the building had already been purchased by another German association, and Yugoslav authorities refused to consider this previous selling of the building as legitimate: the question was solved only after the intervention of the League, which pressed the Yugoslav authorities to give an adequate compensation to the Germans.

Also the Romanians of Timok valley and Macedonia were supported by a Kin State, and this support helped them to get through the difficult atmosphere of the first years. In 1919, for example, the Serbian authorities and troops in Macedonia were accused of refusing to distribute food to Vlachs who could not prove to send their children to Serbian schools; to obstacle the return of Aromenians who left during the war or even to forbid talking in Romanian. ${ }^{10}$

A different condition was that of the Muslim population, who resided in the regions of Kosovo, Macedonia and Bosnia. The Muslims were protected by several clauses inserted in

Petition to the Council of the League of Nations: Re-Violation of the rights of the German minority in the Kingdom of Yugoslavia by decrees and decisions of the Yugoslav authorities herein explained (1930). (League of Nations. Official Journal, 14 ${ }^{\text {th }}$ Year, no.11 (First Part), November 1933, p.1315. HALN, section 41, R1700 dossier 47675.$)$

10 Notes of the Directiunea polipiei o i siguranpiei generale, February 12, 13, 22 1919. Mircea VALCU-MEHEDINTI, Dezvaluiri fapa necunoscuta, a istoriei Romániei. Un popor care se stinge: aromanii (macedo-romanii). Culegere de documente originale din fondurile serviciul special de informapiii direcpiia siguranpiei generale, direcpiia generala a polipiiei, corpul detectivilor casa regala, Bucharest 2008. 
the minority treaty, and enjoyed a form of autonomy in the management of their cultural affairs and in the administration of justice: as a matter of fact, some special judges were competent to decide for the succession and family law according to the religious beliefs of the Muslim people.

The most important Muslim group was that of Bosnia, who was represented by Mehmed Spaho's Yugoslav Muslim Organization and always showed a negotiating approach towards the government of Belgrade. In the occasion of the vote for the Vidovdan (St. Vitus day) Constitution (June 28, 1921), for example, this party carefully negotiated its support, which permitted the government to pass the text with 223 votes out of more than $400 .^{11}$

Bosniaks obtained their minimal demands: a softening in the application of the agrarian reforms, the preservation of their religious autonomy (Islamic judges, Vakuf administration), the religious equality in front of the law, and the territorial integrity of their historical borders around the six Bosnian districts (Sarajevo, Tuzla, Mostar, Travnik, Vrbas and Bihać).

This approach brought the Muslims of Bosnia to contact directly the government, without internationalizing their problems using the instrument of petition. The League, anyway, received some interesting documents concerning the Muslims of Bosnia, who started to develop an inner process of identity construction thinking about themselves as a real Muslim and Slavic nationality, different from the Croats and the Serbs. In 1938, for example, the minority section handled the proclamation of Miloch Valicevic, the duke of Zelich who proclaimed himself as the legitimate heir of the king of Bosnia-Herzegovina, affirming that people of Bosnia claimed their absolute independence under the only legitimate power of the king. According to this document, Bosniaks (le Peuple Bosniaque) had their own character, language, traditions, administration, and precise geographical limits. Bosniaks lived under the Serbian oppression, in an artificial State with no national cohesion, and consequently deserved to exercise their right of self-determination and to be freed from this serfdom, which was described as the: "asservissement des Serbes dans une agglomération de pays en tous points différentes denominée Yougoslavie". ${ }^{12}$

At the end of the interwar period, thus, Bosniaks manifested a certain will of gaining a solid identity and to distinguish themselves from their "Slavic Brothers". These feelings, anyway, were expressed in a very particular period and in very particular ways, for example when in 1943 a group of Muslims submitted a memorandum to the Führer trying to convince him of their Gothic origins. ${ }^{13}$

But, as we previously mentioned the case that most of all interested the League was that of Macedonia. The situation of Macedonia was certainly conditioned by the bad relationships existing between Yugoslavia and Bulgaria, which, in de Azcárate's opinion, could not have been worse; by the activity of the notorious IMRO, the Internal Macedonian Revolu-

\footnotetext{
11 For the conditions of Bosnian Muslims, Adil ZULFIKARPAŠIĆ, The Bosniak, London 1968; Thierry MUDRY, Histoire de la Bosnie-Hercégovine. Faits et controverses, Paris 1999; David A. DYKER, "The Ethnic Muslims of Bosnia: Some Basic Socio-Economic Data", The Slavonic and East European Review, 50/1972, no. 119, 238-256; Mark PINSON (ed.), The Muslims of Bosnia-Herzegovina. Their Historical Development from the Middle Ages to the Dissolution of Yugoslavia, Cambridge Massachusetts 1994. For the national question in interwar Yugoslavia it is obligatory to consult Ivo BANAC, The National Question in Yugoslavia. Origins, History, Politics, Ithaca 1984.

12 This document was received by the secretariat on the $18^{\text {th }}$ of June 18,1938 , and contained the demand of the Duke to appear in the Council to claim the throne. HALN, Section 11, box R3690, dossier 34332.

13 Rade PETROVIĆ, Il fallito modello federale della ex Jugoslavia, Soveria Mannelli 2005, 317-319.
} 
tionary Organization; by the repressive measures of the Yugoslav authorities in the region. These problems were inextricably and reciprocally connected and gave rise to a harsh conflict between Belgrade and Sofia, a dispute which represented a perfect example of what was happening in Europe and in the cases concerning the minorities of many other regions such as Transylvania and Upper Silesia.

The Bulgarian government conditioned the establishment of good relationships with Belgrade to the treatment of Macedonians (who were generally considered as Bulgarians in spite of their attempts of presenting themselves as "Macedonians"); the Yugoslav government, on the contrary, believed that no improvements could be recorded so long as this minority was an instrument used by Sofia for irredentist aims. According to de Azcárate, it was a sort of vicious circle and both parties were partially right, although perhaps neither entirely so. ${ }^{14}$

The activity of the Revolutionary Organization represented a further problem, at least concerning its illegal activities, while it also supported a legal diplomatic action, flooding the League with petitions and protests of many legal associations such as the Macedonian National Committee for the League of Nations, Congress of union of Choral national societies of Bulgaria, Comité national des organisations des émigrés macédoniens, the Committee of the Bulgarian emigrants from Western territories...

These acts were analyzed by the minority section of the secretariat but produced no serious results. The section, as a matter of fact, was limited by the fact that Belgrade openly denied the existence of a Macedonian minority, and this view could not be discussed without creating many more serious problems for the League. The petitions, moreover, had to respect certain requisites, for example they had not to ask for political reforms of the State or territorial changes, they could not be generic and had not to contain expressions of violent language. The Macedonian petitions, on the contrary, often violated all these conditions.

The petition drafted by the committee of emigrants from the Western frontiers of Bulgaria, for example, was full of a spirit of revolt and hostility towards Yugoslavia, as well as the one sent by National Macedonian Committee, on the $22^{\text {nd }}$ of December, $1927 .{ }^{15}$ This violent language was often associated to certain allusiveness and to a lack of precise material references. In July 1926, the petition of Madame Donca Holiotcheva, Présidente de l'Union des Femmes Macédoniennes (based on the association's resolution of 31 May, 1926)

14 On the activity of the Macedonian revolutionaries, even with a sympathetic attitude in commenting and understanding the violence of their struggle, see John BAKELESS, “The Macedonian Question”, Annals of the American Academy of Political and Social Sciences, vol. 177/1935, 223-231; Stoyan CHRISTOWE, Heroes and Assassins, New York 1935; Duncan M. PERRY, The Politics of Terror: The Macedonian Liberation Movements, 1893-1903, Durham 1988; Vermund AARBAKKE, Ethnic Rivalry and the Quest for Macedonia, 1870-1913, Boulder 2003; Albert LONDERS, Terror in the Balkans, London 1935. On the legal propaganda activity of the different Macedonia associations, Voin BOZHINOV - L. PANAYOTOV (eds.), Macedonia. Documents and Materials, Sofia 1978; The Complaints of Macedonia: Memoranda, petitions, resolutions, minutes, letters and documents addressed to the League of Nations, 1919-1939, Geneva 1979.

15 The notes signed by Azcárate in August and December 1927 stressed that the Macedonian petition did not contain any evidence of the existence of such minority and was drafted by a nationalist association. Also the petition of the National Committee of the organizations of the Macedonian emigrants was deemed as not-receivable (note of Colban, April 18, 1927) since it was full of violence, a real political pamphlet against Yugoslavia for the assassination of Mikhail Gavriloff and his son Chrsto. Petitioners accused the authorities as in three weeks the authors of this homicide were not persecuted and punished. The same conclusions were reached for the petition of the National Macedonian Committee (December 22, 1927) for the process of Skopje. (HALN, section 41, box R1700, dossier 51127; box R1661, dossier 12285.) 
contained no allusion to the minority treaties but simply denounced an unbearable regime of terror (un Règime insupportable de terreur) without describing in detail in what this terror consisted. ${ }^{16}$

These petitions mentioned precise political requests which overcame the dispositions of the minority treaties. The executive committee of the Union of Macedonian fraternities, for instance, was warned by British diplomacy "to give up pursuing the chimera of an autonomous Macedonia". ${ }^{17}$ In other occasions, Bulgaria advocated the establishment of an international commission under the auspices of the League, in order to monitor and control the frontiers with Romania, Yugoslavia and Greece as Sofia was repeatedly accused of supporting the revolutionary groups acting in those zones in order to keep high the attention on the "oppressed" Bulgarian minorities.

The Macedonian case was quite exemplar to understand how petitions could be interpreted as a political instrument and exploited in this sense, but at the same time, it showed that repression, police and military measures were absolutely not helpful: on the contrary, they could produce very counter-productive effects. De Azcárate underlined that Serbian iron fist and the "punitive expeditions" ordered against the Macedonian revolutionaries did not conform to the real interest of the State. According to him, it could be easily realized that the policies of persecution and "terrorization" not only constituted manifest violations of the treaties, but also created the conditions in which the revolutionary activities could be carried on to the best advantage.

According to de Azcárate, the League was in a very particular situation when examining the numerous petitions of the Macedonian organizations. On the one hand, the facts constituted "obvious violations of the clause of equality of treatment and security", on the other hand, it was clear that the petitions proceeded from a terrorist organization and the acceptance of the latter meant an encouragement of some activities which aimed to maintain a state of agitation and to prevent the harmonious and peaceful coexistence of majority and minorities.

16 Petition of the Union of Macedonian Emigrant Associations in Bulgaria, (March 5, 1927). In this case, the Persian member of the minorities' section justified the violence of the language. (Jane K. COWAN, "Who's Afraid of Violent Language? Honour, Sovereignty, and Claims-Making in the League of Nations", Anthropological Theory, 3/2003, no. 3, 271-291.) Also the petition of August 21, 1929, of the Union des Bulgares de Bessarabie was considered by the committee for "the absence of details with regard to the grievances stated therein". The committee of three met on January 16, 1930 and considered it was not necessary to bring the matter before the council. (Official Journal of the League of Nations, Issue 5, May 1930, 387)

17 William Erskine suggested to Karanjuloff (the representative of the Executive committee) not to exaggerate with the petitions to the League and "to give up pursuing the chimera of an autonomous Macedonia". (Note of Erskine to the marquess Curzon, Sofia, February 9, 1922, Documents on British Foreign Policy, 1919-1939, First Series, vol. XXIV, London, Her Majesty’s Stationery Office, 1983, doc. 27.) 


\section{Conclusions}

The experience of de Azcárate in the field of protection of minorities ended with the draft of his book, during the second world war, when the minority question had already showed its disruptive potentiality, representing one of the causes of the outbreak of the second world conflict.

The question was deeply connected to the global reform that the peace-treaties tried to impose to the system of international relations, and could be considered as "the keystone of liberalism and one of the fundamentals of democratic organization". ${ }^{18}$ But the work of the League was not merely humanitarian but mainly political, as its aim was to avoid the inter-State frictions and conflicts which had occurred in the past, as a result of the frequent ill-treatment or oppression of national minorities. According to de Azcárate, this target was connected to the international reality and the clash between revisionist and anti-revisionist States, which used the minorities as a sort of Trojan horse, a Fifth Column in order to destabilize their foes and carry out their foreign policy. In 1919, international diplomacy believed that the most effective method of preventing national minorities from disturbing peaceful inter-State relations was to ensure that these minorities received from the respective authorities a reasonable and equitable treatment. Equality was the cornerstone of the protection of minorities: equality before the law, equality of civil and political rights, equal treatment and security in law and in fact, were the main expressions of the minority treaties and the principles which guided the whole system. But these ideas, if generally accepted, met with a wide resistance when they have to be concretely applied:

“(...) those entrusted with the mission of protecting minorities have to carry out their duties in the midst of the strongest political passions, and to intervene in what constitutes the most sensitive sphere of the political life of a country. ${ }^{19}$

The work of the League, as a matter of fact, resented from the troublesome atmosphere of the interwar period, which was imbued with political antagonisms and historical rivalries. However, it represented a first serious attempt in order to create a comprehensive and effective international system; even if for some it has been a failure, the League's protection of minorities proved to be an interesting experiment, and, it has to be underlined, in some cases it prevented many States from exaggerating with the discrimination of their minorities. The general view about this question, anyway, is substantially negative and the League's experience as been seen as a failure, or a defeat of the international system. The study of minority question during the interwar period, an even afterwards, could anyway be very useful to reflect about some conclusions.

During the interwar period, after having gained their independence - sometimes in very brief amounts of time - many States were called to cede part of their national sovereignty to the international institutions, and if this concession could sound just and fair when speaking about the collective security and international peace, at the same time, it was perceived as a great problem when regarding the relation of one State with its citizens. The study of the minorities, therefore, offers interesting suggestions about what could be described

18 Pablo DE AZCÁRATE, League of Nations and the protection of Minorities. An Experiment, Washington 1945.

19 P. DE AZCÁRATE, League of Nations, 27. 
as the Achilles' heel of interwar international regulations, whose development had always been troubled by the lack of some effective instruments to be put into practice and penetrate State boundaries. As a matter of fact, the League was no supernatural being hovering about in space, but consisted of members, each of whom was a sovereign State; only the assumption of a minimum of good faith, together with the common and earnest will of all the members could reduce the animosity of the international relations. ${ }^{20}$

\section{$\cos$}

\section{Documents and Bibliography}

Documents of the Historical Archives of the League of Nations (Geneve)

Vermund AARBAKKE, Ethnic Rivalry and the Quest for Macedonia, 1870-1913, Boulder 2003

John BAKELESS, "The Macedonian Question", Annals of the American Academy of Political and Social Sciences, vol. 177/1935, 223-231

Ivo BANAC, The National Question in Yugoslavia. Origins, History, Politics, Ithaca 1984

Voin BOZHINOV - L. PANAYOTOV (eds.), Macedonia. Documents and Materials, Sofia 1978; The Complaints of Macedonia: Memoranda, petitions, resolutions, minutes, letters and documents addressed to the League of Nations, 1919-1939, Geneva 1979.

Jane K. COWAN, "Who's Afraid of Violent Language? Honour, Sovereignty, and Claims-Making in the League of Nations", Anthropological Theory, 3/2003, no. 3, 271-291

Stoyan CHRISTOWE, Heroes and Assassins, New York 1935

Pablo DE AZACÁRATE, League of Nations and the protection of Minorities. An Experiment, Washington 1945

H. DICKINSON, Les droits des Minorités, Bruxelles 1924

Piotr EBERHARDT, Ethnic Groups and Population Changes in Twentieth-Century Central-Eastern Europe. History, Data, and Analysis, New York - London 2003

Jacques FOUQUE-DUPARC, La protection des minorités de race, de langue et de religion, Paris 1922

Albert LONDERS, Terror in the Balkans, London 1935

Carlile Aylmer MACARTNEY, National States and National Minorities, Oxford 1934

Duncan M. PERRY, The Politics of Terror: The Macedonian Liberation Movements, 1893-1903, Durham 1988

Helmer ROSTING, "Protection of Minorities by the League of Nations", The American Journal International Law, 17/1923, no. 4, 641-660

The Complaints of Macedonia: Memoranda, petitions, resolutions, minutes, letters and documents addressed to the League of Nations, 1919-1939, Geneva 1979

\footnotetext{
20 "The League is no supernatural being hovering about in space. It consists of Members, each of whom is a sovereign State. Therefore the action of the Council cannot be automatic, because the Council cannot meet if not summoned, and cannot be summoned except by the initiative of one of the Members of the League... No transaction whatever, not only between nations but between individuals as well, would be possible without the assumption of a minimum of good faith, and, as the experience of commerce shows, that very assumption, when universal, reduces to a small proportion the number of cases in which that minimum cannot be obtained. The Council, of course, could not hope to settle any dispute were it not supported by the common and earnest will of its Members. (Paul MANTOUX, "On the Procedure of the Council of the League of Nations for the Settlement of Disputes", Journal of the British Institute of International Affairs, 5/1926, no. 1, 16-31)
} 